\title{
A XXI. századi radarrendszerekkel szemben támasztható elvárások
}

\section{Rendszerintegrálási alapok és a radarok zavarvédelmének kapcsolata}

\section{BEVEZETÉS - A TÉMA ÁTTEKINTÉSE}

A cikk célja, hogy a legperspektivikusabb légtérellenőrző radarrendszer-elemek performanciáin (antennajellemzők, zavarvédelem stb.) keresztül bemutassa a rendszerrel szemben támasztható elvárásokat. A szerző több mint 17 éve az ügynökség dolgozója, ennek ellenére, a tanulmányban leírtak kizárólag a szerző saját meglátásait és véleményét tükrözik. A XXI. század radarrendszerei egyesítik magukban a már üzemelő passzív és aktív radarok sajátosságait és kiterjesztik az alkalmazási területeket. [1] Ennek ára, hogy az új „RF hálózatközpontú” radarrendszer egyedi szenzorjai megfelelő ECCM (Electronic Counter-CounterMeasures) vagy újabban EPM (Electronic Protective Measures) rendszerekkel és kommunikációs interfészekkel rendelkezzenek, amelyek lehetőséget biztosítanak az egyes szenzorok performanciájának rejtett, és a lehető legteljesebb kihasználására pl. az aktív zavaró adók alkalmazásának területein. [2, 3] Tételezzük fel, hogy a legmodernebb légtérellenőrző radarok már rendelkeznek digitális, a környezethez és a katonai elvárásokhoz kognitív módon alkalmazkodó adaptív antennanyaláb kialakítási lehetőségekkel, képesek a légtér hullámterjedési együtthatóit meghatározni és a mérési elvárások optimális értékére beállítani, valamint rendelkeznek az egyedi radarplatformok „kiterjesztett hatásfokú” és szélessávú ECCM/EPM rendszereivel. Ha ez megvalósul, a modern radarba csak a „RF hálózatközpontú” radarrendszerhez való csatlakozási interfészt kell beépíteni. Ugyanakkor a „RF hálózatközpontú" rendszer természetbarát, így költséghatékony megoldásokat találhat a már üzemben lévő radarok integrálására. Ennek célszerű módja a meglévő radarok ECCM/EPM ké-

1. táblázat. A légtérellenőrző radarantennák jellemzői

\begin{tabular}{|l|c|c|c|c|}
\hline \multirow{2}{*}{\multicolumn{1}{c|}{ PARAMÉTER }} & \multicolumn{4}{c|}{ RADARTíPUS } \\
\cline { 2 - 5 } & P-14 & Kaszta-Parol & P-37 & RAT-31D \\
\hline Ant. diagram & Magas/Alacsony & Magas/Alacsony & $5 \times$ túnyaláb & Komb. tünyaláb \\
\hline Ant. erősítés [dB] & Közepes $(>20)$ & Közepes $(>30)$ & Nagy $(>35)$ & Nagy $(>35)$ \\
\hline Pillanatnyi BW / Ant. BW [MHz] & Kicsi $(<1)$ & Kicsi $(<1)$ & Kicsi $(<2)$ & Nagy $(>2)$ \\
Közepes $(<100)$ & Közepes $(<200)$ & Nagy $(>400)$ & Nagy $(>200)$ \\
\hline Frekvenciatartomány / Polarizáció & VHF/H & UHF-L/H-V & S/V-Circ. & L/H \\
\hline
\end{tabular}

Rövidítések: Ant. - antenna, BW - sávszélesség

ÖSSZEFOGLALÁS: A XXI. század korszerű légtérellenőrző és légvédelmi rendszerei számára alapvető elvárás a radarok zavarvédelmének kiterjesztése és rendszer szintü, a ma alkalmazott megoldásoknál hatékonyabb módszerek bevezetése. Erre azért van szükség mert a környezeti elektromágneses interferencia néhány frekvenciasávban jelentősen megnövekedett, ugyanakkor katonai eszközök esetén joggal feltételezhető, hogy a korszerü aktív zavaradók hatékonyan képesek semlegesíteni az egyedi radarokat. A cikk a mobil radarok, mint rendszer alapelemek müszaki sajátosságaival, az elektronikai védelem antennához kapcsolódó lehetőségeinek bemutatásával és az „RF (rádiófrekvencia) hálózatközpontú” üzemeltetés elvárásaival foglalkozik. Összegzésre kerülnek a szoftver radar logisztikai biztosítás napjainkban még csak alig érzékelhető kihívásai.

KULCSSZAVAK: rádiólokátor, passzív radar, RF hálózat központú radarrendszer, aktív zavarvédelem - ECCM
ABSTRACT: It is essential requirements of a modern air surveillance and air defense systems in the XXI century to expand the ECCM (Electronic CounterCounterMeasures) performance of the individual radars at the radar systems level, and to introduce more efficient methods for today's solutions. This is necessary as environmental electromagnetic interference/smog has increased considerably in some frequency bands. While, in the case of military devices, it can be reasonably assumed that advance jammers can effectively override the radar's Electronic Protection Measures (EPM). This study deals with the technical features of mobile radars as basic components of radar systems, examines the antenna-related ECCM capabilities of the radars and performance, and the "built-in" requirements of the „RF Network based” operation. It summarizes the software radar logistics insurance in the days of exploring the challenges that are still barely perceived.

KEY WORDS: radar, passive radar, RF network centric radar systems, Electronic Counter-Countermeasures

\footnotetext{
Vezető mérnök, Hírközlési, Légi és Rakétavédelmi Program Mérnöki Támogató Osztály; NATO Beszerzési Ügynökség ORCID: 0000-0003-3566-2904
} 


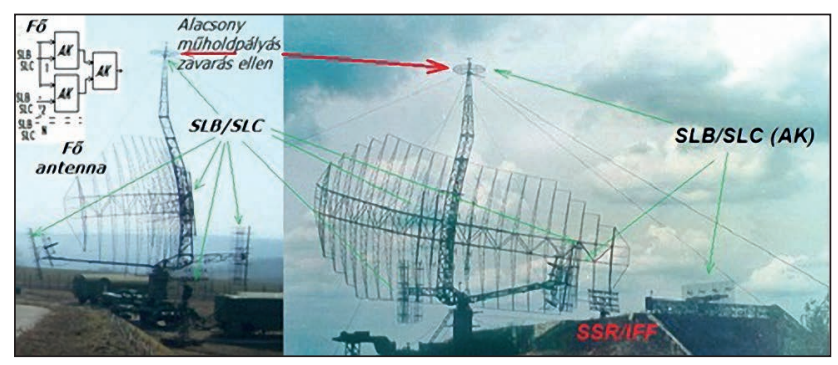

1. ábra. $A$ Tall King (P-14, Oborona) radar antennarendszere az SLB-SLC antennákkal

pességeinek kihasználása, illetve ezeknek az új elvárások szerinti kiépítése. Az 1. táblázat összefoglalja a Magyar Honvédség számára rendelkezésre álló radarantennáknak az „RF hálózatközpontú” rendszer szempontjából is kihasználható föbb paramétereit.

Az 1. táblázat megmutatja, hogy a radarantenna - a leghatékonyabb térbeli szűrőként - eszközein keresztül milyen lehetőségekkel rendelkezik a továbbfejlesztésre. A radarok zavarvédelmének legfontosabb eszköze a kombinált oldalnyaláb-blankolás - oldalnyaláb elnyomás (Side Lobe Blanking - Side Lobe Cancellation), ahol az SLB a nagyteljesítményű rövid impulzusokat „blankolja”, míg az SLC a nagykitöltési tényezőjü zajzavar típusú zavarok irányában csökkenti a radarantennán vehető jelek erőségét. (Orosz terminológia szerint SLC = AK - Autokompenzátor.) Az ECCM/EPM antennák elhelyezésére látható példa az 1. ábrán.

Az SLC modul akkor működik hatékonyan, ha a rendszer kimenetén a zajzavar teljesítménye elhanyagolhatóan kicsi, míg a céltárgyakról visszaverődött impulzusok teljesítményét nem csökkenti. Így az SLC rendszer arra „törekszik”, hogy teljesüljön az alábbi feltétel:

$$
\dot{F}_{0}\left(\theta_{j}\right)+\sum_{i=1}^{N} \dot{K}_{i} \dot{F}_{i}\left(\theta_{j}\right)=0
$$

ahol:

$$
\dot{F}_{0}\left(\theta_{j}\right) \text { - A referens/bázis radarantenna-diagram komplex }
$$
függvénye;

$\dot{F}_{j}\left(\theta_{j}\right)-A z, ; "$ radarantenna komplex függvény performanciája a ,j" zavaró adó irányokban, $j=1 . . . M$;

$\dot{K}_{i} \quad-A z$ „i" radarcsatorna átviteli függvénye komplex korrelációs tényező, a referens/bázis radarantennához viszonyítva.

A zavarelnyomási tényező („,K”) a vizsgált rendszer bemeneti és kimeneti jelteljesítményeinek arányából származtatható:

$$
K=\sigma_{\text {in }}^{2} / \sigma_{\text {out }}^{2}=1 /\left(1-|\rho|^{2}\right)
$$

ahol: „, komplex korrelációs tényező.

Ismert, hogy a korrelációs tényező (,O") a vizsgált rendszer bemeneti és kimeneti jelek közötti lineáris kapcsolat arányából számítható ki. A korrelációs időintervallumra vonatkozó vizsgálatok egy részét (pl. a jelek integrálása, a fázisvezérelt antennák, a passzív és aktív zavarelnyomás eseteiben) közzé tették a szakirodalomban, de az ismeretek radarrendszer-integrálási szempontokat meghatározó jelentősebb hányada napjainkban még nem publikus. Ezért előfordul, hogy a radarrendszerek gyártói és a vevők értelmezése eltér abban, hogy mit tekintünk a radarrendszer bemeneti és kimeneti jelfolyamának. Példaként vegyünk egy SLB-SLC alapú zavarvédelmi rendszert. (Lásd 1. ábra.) Adott, a 20 dB-es zavarelnyomási elvárás, amelynek eléréséhez $\rho=0,99$ korrelációs érték realizálása szükséges, amely már a 1970-es évek radartechnológiai szintjén is megvalósítható volt. Ugyanakkor a 40 dB-es zavarelnyomási érték eléréséhez $\rho=0,9999$ korrelációs értéket kell biztosítani, amely még napjaink technológiai lehetőségei tükrében is komoly kihívás. (Sőt, néhány gyártó a radarok zavarelnyomását $50 \mathrm{~dB}$ vagy e fölötti értékben adja meg.) Miért és hogyan lehetséges ez? A válasz egyszerű, ha csak a jelfeldolgozó egység bemenete és kimenete közötti jelteljesítmény értékekkel számolnak, mivel a felhasználó nem írta elő, hogy a környezeti rendszerhatások kompenzálásáért (pl. antenna-, adórendszer jelstabilitás hőmérséklet függése, hullámterjedési sajátosságok) a gyártó a felelős. A korrelációs együtthatók 1-hez nagyon közeli értékeit azért nehéz biztosítani, mivel értéke eleve behatárolt az adó- és vételi rendszer jelátviteli függvénye, az RF egységek linearitása, dinamikája, a párhuzamosan üzemelő csatornák egymásra hatása és a hullámterjedési közeg változásának paraméterei által.

A lehetőségeket tovább rontják a környezet és a céltárgy által okozott torzítások és az a tény, hogy a vevőrendszer és a jelfeldolgozás performanciája szintén véges. A felsorolt hatások mellett a zavaró jelek szűrését az állócélok és külön az aktív zavarforrások korrelációt rontó hatásai is csökkenthetik. Ezért minden radartípusra igaz a megállapítás, hogy külön kell mérni, értékelni és kalibrációs módszerekkel maximalizálni az adórendszer, a jelterjedési utak, a céltárgy és a vételi csatornák által biztosítható korrelációs értékeket és ezek megvalósíthatóságának gazdasági vonzatait. Egy adott radarrendszer által elvárt korrelációs tényezőt gyakori alrendszer- és rendszer-kalibrációs mérésekkel folyamatosan pontosítani kell. Napjainkra ezt minden komolyabb radargyártó cég alkalmazza, hiszen a korszerű radarrendszerek működéséhez elengedhetetlen feltétel a korrelációs együtthatók értékének pontos mérése, és ha szükséges az eltérések (jelkésések, torzulások és fáziscsúszások) korrigálása. A kérdés csak az, hogy a gyártók által ajánlott rendszerek a valóságban, milyen korrelációs tényező/együttható értéket tudnak realizálni, és ezt az értéket milyen hosszú ideig lehet fenntartani a radar élettartamciklusa alatt? Miért kell erre fokozott figyelmet fordítani? Mert az Adójel teljesítményparamétereit meghatározó jellemzők az adó átlagteljesítménye, az adóantenna nyeresége a mérés irányában, adóoldali átviteli veszteség (tápvonalak, antenna), az adó és a céltárgy közötti hullámterjedési tényező, valamint az adórendszer által biztosított koherens jelfeldolgozás időtartama ( $\mathrm{n}$ - impulzus szám/ jelfeldolgozási ciklus esetére), ha kismértékben is, de az üzemeltetés során változik. A Céltárgyhoz kapcsolható tényezők a céltárgy hatásos keresztmetszete/fluktuációja a radar üzemeltetési frekvenciáján az adó, a céltárgy és a vevőpontok közötti távolság, valamint a polarizációs együttható a céltárgy típusa és mozgásparaméterei függvényében változnak. A Vevőrendszerhez kapcsolható tényezők a vett jel teljesítményparamétereit meghatározó jellemzők, a vevőantenna nyeresége a mérés irányában, a vevőrendszer zajteljesítménye, a céltárgy és a vevőpont közötti hullámterjedési tényező, a vevő és a jelfeldolgozás által biztosítható koherens jelfeldolgozás-időtartam, valamint a vevőoldali jelátviteli veszteségek, amely értéket az elektronikai harc körülményei jelentősen növelhetnek, szintén dinamikusan változó paraméterek.

További lényeges követelmény, hogy a kalibráció beállítására vonatkozó elvárásoknak úgy kell megfelelni, hogy észrevehetően ne csökkenjen a radarrendszer fő feladataira, a céltárgy paramétereinek mérésére fordítható idő.

A 2. ábra az „RF hálózatközpontú” radarrendszer működéséhez szükséges interfész struktúrát mutatja be. Alapve- 


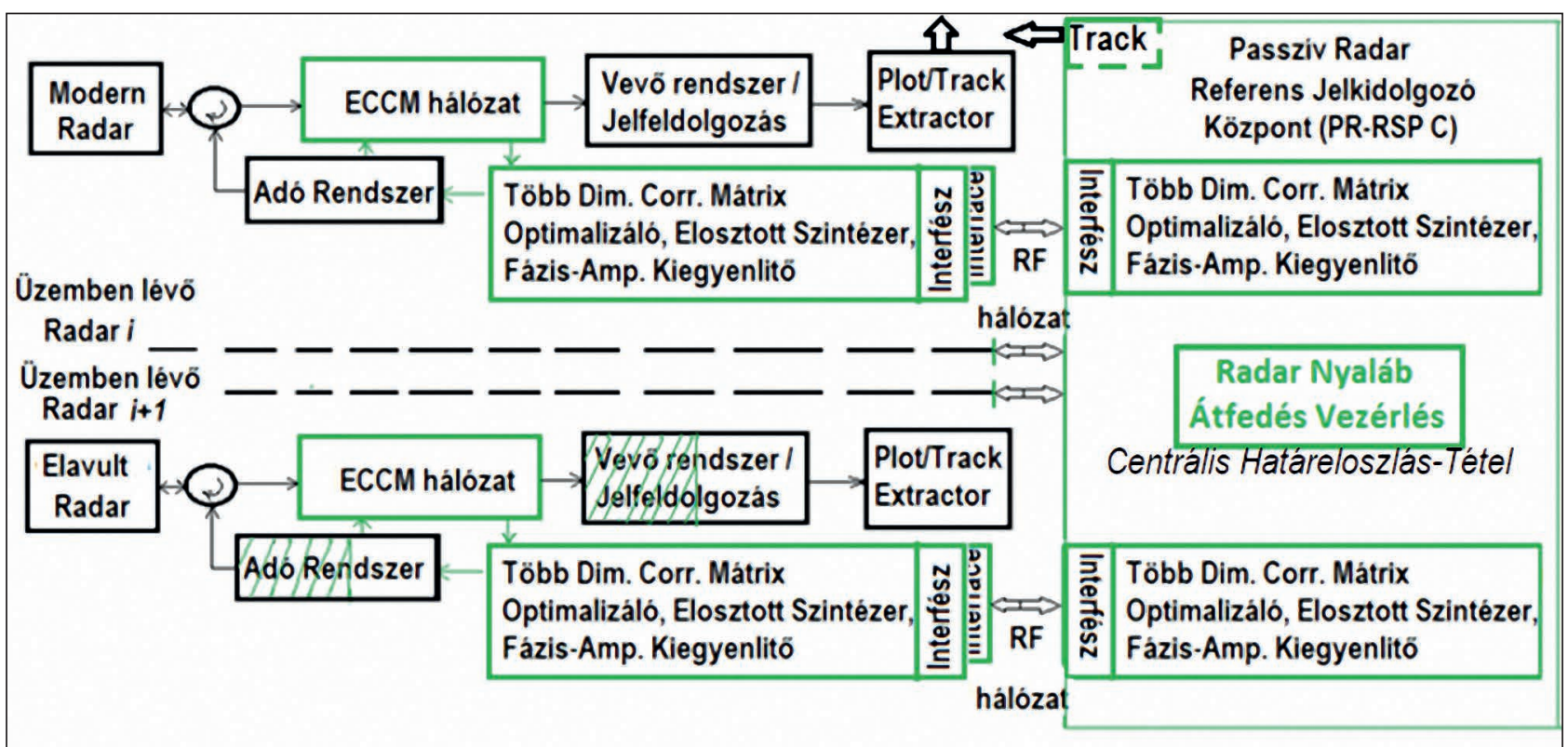

2. ábra. „RF hálózatközpontú” - kvázi - monostatikus rendszer radar interfészének struktúrája

tő elvárás, hogy a rendszerbe kapcsolt valamennyi radar továbbra is biztosítsa a jelenlegi üzemeltetéshez szükséges plot/útvonal adatformátumok küldését az adatfeldolgozó központba. Ezen a területen nincs változás. A modern 4-k 5-k generációs radarok - egyben az új rendszer referencia radarjai - rendelkeznek a rendszerintegrálást biztosító interfésszel. Ugyanez a blokk/interfész megtalálható a Passzív Radar Referencia Jelkidolgozó Központban (PR RSP C - Passive Radar Reference Signal Processing Centre). [1] Ezen és a kialakított kalibrációs hurkokon keresztül szinkronizálható a rendszer működéséhez szükséges „több dimenziós korrelációs mátrix”, az „elosztott szintézervezérlés", valamint a vett jelek amplitúdó-fázis kiegyenlítése. A szabványos interfészt minden radarba, és/ vagy a rendszer részét képező aktív zavaró rendszerbe beépítik.

Az interfészek száma megegyezik a hálózatba kapcsolt radarok számával. A központi vezérlés számára kiemelt jelentősége van a „radarnyaláb átfedés-vezérlés” munkaállomásnak, mivel itt jelölik ki azokat a térrészeket, légtérellenőrzési fő irányokat, amelyek kiemelt „figyelemben” részesülnek. Ezeken a térrészekben a céltárgyak az átlagosnál nagyobb valószínűséggel és gyakrabban detektálhatók, valamint a nem együttműködő repülő eszközök azonosításához kiegészítő információ gyűjthető. A légtérben zajló folyamatok változása: a repülési útvonalak, az aktív-passzív zavarhelyzet, a hullámterjedési tényezők 7080\%-ban „normál eloszlás függvény” szerint írhatók le. Ugyanakkor az esetek 20-30\%-a ettől eltérő, a vezetés számára kiemelten fontos folyamat. A „centrális határeloszlás tétel” algoritmusaival folyamatosan értékelhetők a légtérben megjelenő az „átlagostól” eltérő folyamatok, amelyek elősegítik a döntések időbeni kidolgozását, saját tevékenységünk rejtését. A rendszer kihasználhatja és maximalizálja a már üzemben lévő radarok performanciája nyújtotta lehetőségeket, és teret kínálhat az aktív fázisvezérelt antennák aktív zavarásra történő alkalmazási lehetőségeinek kiterjesztésére. Ez akkor lehet hatékony, ha a radar ECCM/EPM rendszerét teljesen feljavítják, új üzemmódokat alakítanak ki, pl. lecsökkenthető az antenna forgási sebessége, amely által jelentősen növelhető a céltárgyakra fordított megfigyelési idő és/vagy növelhető a zava- ró teljesítmény. Ez néhány esetben részleges adó- és vevőrendszer modernizációt is magába foglalhat. A „passzív radar referens jelkidolgozó központ" a kiértékelt jelentésekből fél másodperces gyakorisággal útvonalakat képez, amelyeket elküld a központi harcálláspontokra. A hatékony „RF hálózatközpontú” radarrendszer kiépítése szempontjából a mobil radarrendszerek határozzák meg a rendszer referenciaadatait, ezért ezek lehetőségeit részletesebben elemezni szükséges.

\section{A MOBIL RADAROK PERFORMANCIÁJA}

Mobil radarok legfontosabb performanciáit és árát a mobilitással kapcsolatos követelmények határozzák meg. Ezek többek között: a telepítési és bontási idők, (rendszerektől függően 10-60 perc), a légi helyzet adatfrissítés gyakorisága, amely általában 2-12 s között választható.

A követelmények teljesíthetőségének érdekében a gyártók kompromisszumok megkötésére kényszerülnek a felhasználókkal, hiszen kisebb tömegek mozgatása és kiszolgálása egyszerübb és könnyebben megoldható. Ennek következtében az antennaméretek, az adóteljesítmények

\section{3. ábra. A TRML-3D radar antennarendszerének telepítése}

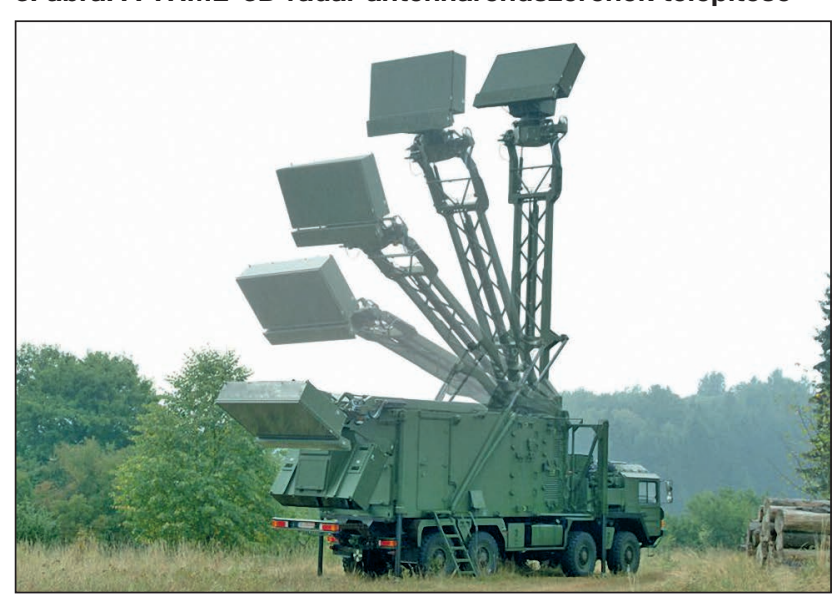




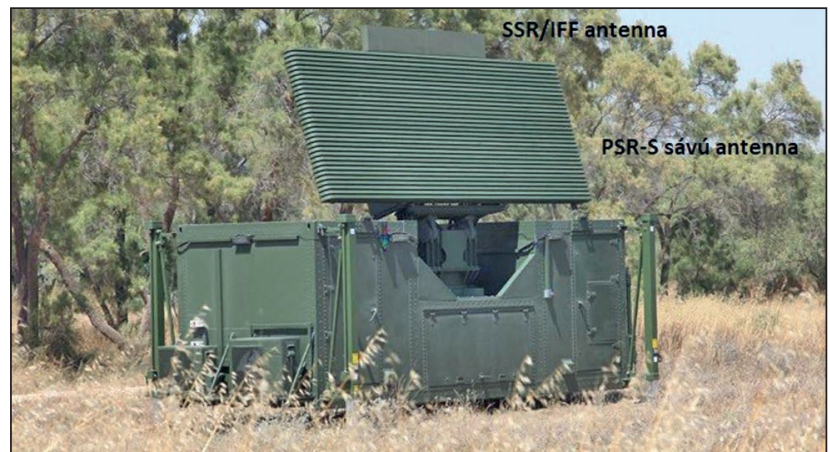

4. ábra. Izraeli gyártmányú S-sávú mobil radar

jelentősen kisebbek, mint azonos családba tartozó és azonos funkcionális elemeket tartalmazó fix telepítésű társaiké. A 3. ábrán látható TRML-3D radar megfelel ezeknek a követelményeknek, a C frekvenciasávban (5-6 GHz) üzemel, ezáltal kihasználja a magasabb frekvenciatartomány antennanyereségben, mérési pontosságban jelentkező előnyeit. 200 km-en belül képes detektálni és követni a kis magasságú légi célokat. A kétfős kezelőszemélyzet 300 méter távolságból távkezeli.

Új képességeiben megnövelt verziója TRML-4D néven 2020-ban kerül az első megrendelőhöz. Hasonló műszaki paraméterekkel rendelkezik a svéd SAAB által gyártott Giraffe $4 A$ radar, amelynek nagyobb teljesítményű változata a Giraffe $8 \mathrm{~A}$ is megrendelhető. A SAAB rendszerek moduláris szoftverstruktúrája, Björn Engström szerint lehetőséget biztosít egy modern VHF frekvenciasávban üzemelő radarrendszer család gyors kidolgozására. [4]

A 4. ábrán látható S-sávú, vízszintes antenna polarizációt alkalmazó mobil radar telepítési ideje hosszabb, mint a TRML-3D radaré, de ezért cserébe polgári vontatók használhatók a radar áttelepítéséhez. A szabványos konténerek alkalmazása a berendezések és az antennarendszer elhelyezésére jelentősen csökkenti a fenntartási költségeket. [5]

Itt kell felhívni a figyelmet arra, hogy a mobil radarrendszerek legfontosabb rendszertechnikai kérdésköre a másodlagos rádiólokációval (SSR - Secondary Surveillance Radar) megoldott saját-idegen felismerő berendezések (IFF - Identification Friend or Foe) rendszerbe integrálásának mikéntje. A 4. ábrán látható SSR/IFF berendezés megfelel a minimális elvárásoknak, amelyeket a feladat ellátásához szükséges adóteljesítmény, vevőérzékenység, oldalszögben $10-45^{\circ}$, míg helyszögben $20-50^{\circ}$ félteljesítményű antenna iránykarakterisztika jellemez. A céltárgy-azonosítás, Mode-1, Mode-2, Mode-3/A, Mode-3C, Mode-S, Mode-4 és Mode-5/nemzeti, a polgári légi forgalomban használt frekvenciákon történik, és hagyományos PSR, valamint SSR/IFF plot és/vagy útvonal alapon kerülnek egyesítésre és továbbításra a harcvezetési központba.

\section{VHF-SÁVÚ MOBIL RADAROK}

A 5. ábrán az ukránok által modernizált P-18/2000 VHF sávban üzemelő radar látható. A legfontosabb gyári adatok: maximális céltárgy detektálási távolság $250 \mathrm{~km}$, a céltárgy oldalszög mérési pontossága: $0.4^{\circ}$, az oldalnyalábon keresztül érkező aktív fehér zajzavar elnyomása $25 \mathrm{~dB}$, passzív zavar, álló célok, chaff, elnyomás $40 \mathrm{~dB}$, átlag adóteljesítmény 800 watt (16 kW impulzusban), jelkompresszió.

Kiemelt jelentősége van a tartóoszlopon látható, fixen rögzített négy kisegítő vízszintes polarizációt alkalmazó antennának, amelyek feladata a főantenna hátsó és oldal-

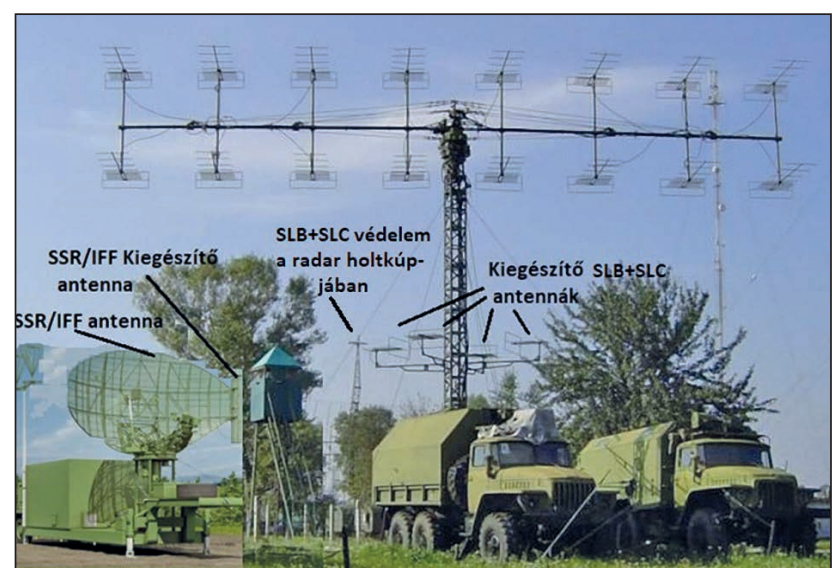

5. ábra. Ukránok által modernizált P-18/2000 VHF radarmérőpont

nyalábjain vett jelek detektálása a radar aktív zavarvédelmi rendszerei SLB-SLC számára. Ezt a módszert a cseh Retia cég is átvette és a vietnámi légtérellenőrzés is rendszeresítette. A kép közepén a radar holtkúpja irányából érkező (LOS vagy drónokra szerelt) zavaró adók jeleinek szürésére szolgáló segédantenna látható.

A 5. ábra bal alsó sarkában található SSR/IFF berendezés ugyanazokat a feladatokat teljesíti, mint a 4. ábrán bemutatott müszer, mégis az antennarendszer nyeresége néhány százszor nagyobb, szélesebb frekvenciasávban áthangolható és kiegészítő antennákkal van ellátva. (A Magyar Honvédség 1990 elején közel félszáz, az itt bemutatotthoz nagyon hasonló, SSR/IFF berendezéssel rendelkezett.) Vajon mi célból van/lehet erre szükség? A kiegészítő antennák és az üzemi frekvenciasávok áthangolása egyértelműen az aktív zavarvédelem lehetőségeit terjeszti ki és hatásfokának növelését szolgálja. Ugyanakkor a nagy antennanyereség arra utal, hogy a SSR/IFF rendszer primer radar feladatokat is ellát. Miért célszerű ez? A SSR/IFF rendszerek függőleges polarizációjú és komplex modulációval rendelkező nagyteljesítményű impulzusokat használnak az IFF feladatok ellátására. Ezeknek a jeleknek a kihasználása primer rádiólokációs feladatokra jelentősen kiterjeszti az egy települési helyen található radarok mérési szabadságfokát, zavarvédelmét, hiszen polarizációban, frekvenciában és jelkompresszióban eltérnek a primer radarok vízszintes polarizációjú antennáinak jelfeldolgozásához képest. Egy ilyen rendszert megnövelt SNIR, adat- és jelfeldolgozás lehetőségek és a célról származó gyakoribb jelentések jellemeznek. Természetesen ez az új üzemmód nem csökkenti a SSR/IFF feladatok performanciáját, hiszen a szekunder és primer radarjelek a koherens jelfeldolgozással párhuzamosan történnek.

\section{A METEOROLÓGIAI RADAROK LEHETŐSÉGEI}

Az időjárás-radarok új nemzedékének megvalósításán dolgozik Kurt Hondl és csapata, akik a nagyteljesítményű, nagyon tiszta jel-előálítással és jelfeldolgozással rendelkező, párhuzamosan két polarizációt használó fázisvezérelt antennák előnyeinek kihasználásában látják a jövőt. [3] Az új S-sávú radar közel 5000 adó-vevő modult tartalmaz, 24 párhuzamosan üzemelő vízszintes és függőleges polarizációt alkalmazó adó-vevő alrendszerbe szervezve. Az elektromosan mozgatott iránykarakterisztikák helyszögben $40-60^{\circ}$ os térrészről 2-3 másodpercenként képes megbízható időjárás és atmoszféra állapotjellemzőket szolgáltatni. A radar 
még nincs kész, de már a mostani eredmények is nagyon biztatóak az időjárással kapcsolatos információk tekintetében és a nagyon kis radarkeresztmetszettel rendelkező célok detektálásában. A mérési adatok feldolgozásával kapcsolatos eredmények egyre pontosabb kiértékelésével talán új felhasználási terület nyílik a a lopakodó/nagyon kis visszaverő felülettel rendelkező repülőeszközök által keltett turbolencia jelenségek kimutatásában. Ez a megoldás, ha működik, hasonló a tengeralattjárók periszkópja által keltett hullámok detektálása és útvonalba fogása technikához, amikor magát a periszkópot nem látjuk. Itt kell megjegyezni, hogy meglévő radarjaink is képesek időjárási adatok szolgáltatására, csak az információ kinyerésének mikéntjét kell megoldani. Ez előírható pl. az „RF hálózatközpontú” radarrendszer ECCM/EPM alrendszer követelményeiként.

\section{A KRASUKHA PASSZÍv RADARRENDSZER}

A 6. ábrán látható Krasukha-4 EW - elektronikai harc és passzív radarrendszer-mérőpontok az orosz-ukrán haditechnika eredményei. Gyorsan, menetből telepíthető, több frekvenciasávban különösen kifinomult méréstechnikával rendelkeznek, elődjéhez, a Kolchuga passzív radarantenna-rendszerhez képest [1] a továbbfejlesztett antennarendszerek, egymástól 60-80 dB izoláltak, és ezáltal jelentősen növelhető az elvárt korrelációs együttható érték. Ezáltal a rendszerzavaró performancia, az összetett modulációs módok, a csúcsteljesítmény és az antennanyaláb-iránybeállítás hatékonyága növelhető. A passzív rendszereknél szokásos módszerhez hasonlóan a középső antennaárbócra sűrűn egymás mellé telepített, széles frekvenciasávot lefogó elektromos antenna iránykarakterisztika vezérléssel antennaelemek találhatók. Így $360^{\circ}$-os oldalszög-tartományban párhuzamosan gyűjthető és értékelhető az RF spektrum. Az „érdekesebb RF jelenségek” adott szektorokban nagy nyereséggel rendelkező és monopulzusos rendszerben üzemelő antennák jeleivel részleteiben, nagy felbontással vizsgálhatók. A mért jeleket/adatokat helyben és központilag kiértékelik, illetve feldolgozzák, és ha célszerü, zavaró adóként is üzemel.

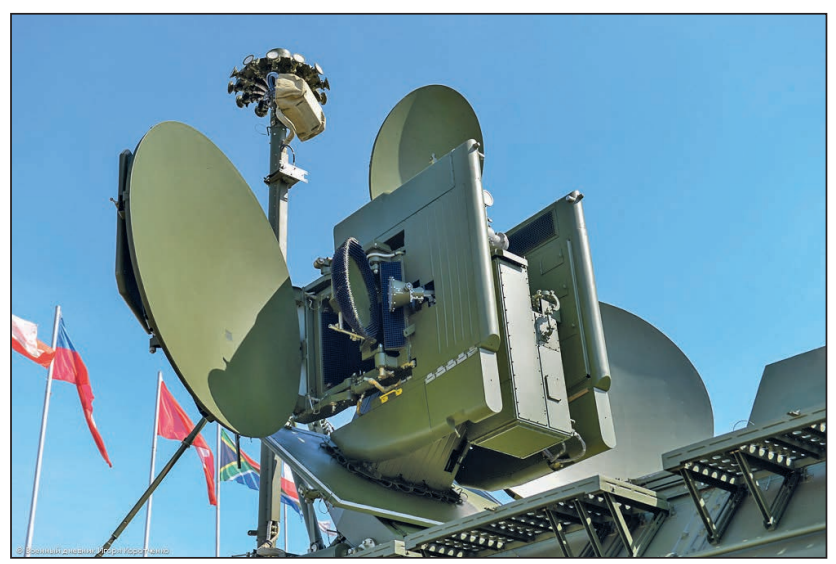

6. ábra. Orosz gyártmányú mobil EW - elektronikai harc- és passzív radarrendszerek (Krasukha-4)

\section{A KORSZERÜ RADARRENDSZEREK BESZERZÉSÉNEK ÉS FENNTARTÁSÁNAK PROBLEMATIKÁJA}

A világ legnagyobb katonai logisztikával foglalkozó ügynöksége az NSPA, amely 60 éve gyűjti a katonai berendezések, és azok logisztikai támogatásával kapcsolatos ta- pasztalatokat. Fő megrendelői - fontossági sorrendben - a NATO katonai vezetése, a NATO-tagállamok, a partnerség a békéért országok és néhány, a NATO számára különleges státusszal/kapcsolattal rendelkező ország. A légvédelmi program szakemberei a NATO országokban rendszeresített radarok performanciáit 1997 óta rendszeresen mérik.

A haditechnikai berendezések/eszközök fejlődésével a beszerzési harcászati-műszaki elvárások és a logisztikai támogatás mikéntje folyamatos átalakuláson ment és megy keresztül. Régebben, és bizonyos rendszerek esetén még napjainkban is, a meghibásodások egyszerűen kezelhető módjai dominálnak. A szoftver-megoldásokkal nagyon kis mértékben támogatott sok cserélhető modult, müködési egységet, alrendszert tartalmazó eszközök javítása költséghatékonyan megoldható a helyben rendelkezésre álló müszaki gárdával. Még néhány évvel ezelőtt is a radarok alapvetően modul szintű részegységekből tevődtek össze, amelyek jelentős részét a „kisegítő” áramellátó, hűtő/fütő és antennaforgató rendszerek tették ki. Már ebben a konstrukcióban is a beépített szoftver megoldások logisztikája döntő jelentőséggel bírt. Később a radarokhoz rendszeresített személyi állomány csökkenésével, a szoftver alapú megoldások térnyerésével előtérbe kerültek az integrált logisztikai támogatás módszerei, ahol helyben csak modul/egység szintű cserék és az előirt karbantartási ciklusok elvégzése az elvárás. A modulok javítása és a magasabb szakmai szintet igénylő feladatok megoldása a gyártó feladata. A gyártó által biztosított teljes körű logisztika, elvárásként folyamatosan terjed a légtérellenőrző rendszerekbe beépülő IT-alapú megoldások növekedésével. E módszer kézenfekvő előnye, hogy a kezelőállomány jelentősen csökkenthető, de annak képzettségi fokát fent kell tartani. (A kezelő a szoftveres beállításokat használja, de azt tudnia kell, hogy ez milyen hatással van a radar performanciára.) Hátrányként szokás említeni a vállalat rendkívül magas rendelkezésre állási költségeit, a szerződésen kívüli, jogilag nem egyértelmű feladatok idő- és költségvonzatait, a nem tervezett feladatok nehezen becsülhető extraprofit hányadát és a gyártó cég esetleges csődjét. A problémák érzékelésére jó példa a radar környezetében érvényes hullámterjedési tényező meghatározása és a radarba történő bevitelének módja. A helyi információforrásokkal pontosított hullámterjedési tényező, amely értékek légkör, időjárás és magasság szerint változó adatok, radarjel-feldolgozásba való bevitele lehet kézi vagy automatikus. A kézi adatbevitel egyszerű, gyakran alkalmazzák, de nem hatékony. Az automatikus bevitel interfészre vonatkozó elvárásokat viszont előre a felhasználónak kell meghatároznia és az adatokat az élettartam-ciklusra vonatkozóan biztosítania. Kérdés kinek miért kell felelnie? A kockázatok csökkentésének célszerű módja, ha nemzetközi tender keretében részletes szabályozzák az átvételi performanciák tesztelésének módjait, a berendezés logisztikájával kapcsolatos elvárásokat, beleértve a kezelőszemélyzet számát és képzettségét, a javítókészletek mennyiségét, feltöltöttségét, az üzemeltetési/ kiképzési segédanyagok minőségét és a gyári beavatkozások elvárásait. Ennek ellenére a hazai kapacitásokat célszerű valamilyen formában fenntartani, hiszen a berendezésgyártók a katonai alkalmazási módokat, a továbbfejlesztési elvárásokat nem adják meg. A radarrendszerek 70-90\%-a szoftver és IT-rendszer alapú, amelyet úgy kell 15-20 évig felelősségteljesen üzemeltetni, hogy az ITrendszerek performanciája 1-2 évente duplázódik. A cserére szoruló COTS (polcról levehető) IT-termékek/eszközök rendszerbe illesztése még az eredeti gyártó által is rendkívül költséges és kockázatos. [3] A szerződés meg- 
kötése után általában 5-8 évvel jelentkező jogos katonai fejlesztésekről, modernizálásról szóló megállapodásokat csak az eredeti csak az eredeti szerződő féllel kell/lehet megkötni, ahol az új katonai elvárások teljesítése egy nagyon profitorientált cég vezetésének kezében van. Ezek alapján rendkívül kockázatos feladat a berendezések élettartam-ciklusra, 15-20 évre szóló gyártó általi támogatás feladatainak és a tender kiírásának megfogalmazása. Egyes nemzetek pl. az osztrákok, a kockázatokat azáltal csökkentik, hogy ragaszkodnak a berendezések modulszintű javítási képességeinek és az IT-támogatás hazai bázisának, legalább SW modul szintű megteremtéséhez és gyártó általi támogatásához.

Az interneten fellelhető adatokból ismert, hogy a TRML3D radar ára 10-12 millió euró, mint a legtöbb mobil radaré, amely jól megfogalmazott hasonló harcászati-műszaki paraméterekkel rendelkező nemzetközi tender eredménye. [4] Egyedi, tender nélküli vásárlások esetén az ár elérheti a 14-15 millió eurót. [6] A passzív radarrendszerek ára, három mérőponttal számolva, a 2. ábra és a kiépítettség elvárásai függvényében 10-40\%-a mobil radarok árának. A VHF radarok költségei harmada/ötöde a hasonló feladatokat ellátó L- és S-sávú társaikénak.

Minden ország jogosan várja el, hogy nagy értékű beszerzéseiben a nyertes fél minimálisan a vásárlás értékének 30\%-ában hozzájáruljon a hazai ipar fejlesztéséhez. Így minden esetben előtérbe kerül a pénzügyi gazdasági elvárások politikai vetülete. Jogosan merül fel a kérdés, hogyan, milyen módszerekkel lehet a beszerzés kockázatait, árát csökkenteni és a kiépítendő radarrendszer indulási harcászatiműszaki paramétereit, a 15-20 évre számolt logisztika megbízhatóságát, hadrafoghatóságát és az esetleg felmerülő új követelmények beépíthetőséget maximalizálni.

Tapasztalatok szerint ennek legjobb módszere, ha a vásárló el tudja hitetni magáról és professzionális módon tudja, mit akar harcászati-műszaki és az élettartam ciklus vonatkozásaiban, elvárásai a kor színvonalán állnak, rendszerben gondolkozik és csak olyan elvárásokat támaszt, illetve fogalmaz meg, amelyeket átvételkor pontosan ellenőrizni tud. Komoly előnyök származhatnak abból, ha a tenderkiírás teljesítése, referenciaként jelentősen emeli a kivitelező presztízsét. Ilyen, ráadásul reális és költségkereteken belül megvalósítható kihívásokat támasztani csak olyan szakembergárdával lehet, akik a valóságban is ismerik a radarok légvédelmi rendszer performanciáit és a korszerű, közeljövőben is hatékony elvárásokat. A szerző szerint ennek legjobb módja egy olyan nemzetközi tender megfogalmazása, ahol a legjobb értékaránnyal rendelkező ajánlat dönt és a döntés a harcászati-műszaki követelmények (pl. 50\%, amelyből legalább $20 \%$ hazai beszállítói hányad), logisztika (25\%, amelyből legalább $10 \%$ hazai beszállítói hányad), politikai preferáltság (25\%). A sikeres tenderhez legalább 80\%-ot kellene teljesíteni.

\section{Összegzés}

A közeljövő korszerű légtérellenőrző rendszerei „RF hálózatközpontúak", amelyek szerves részét képezik a fix telepítésű rendszerek, passzív és mobil szenzor elemek. Általánossá válnak az egyedi hordozó platformra szerelt érzékelő és csapásmérő eszközök, közös RF szinten összekapcsolt erőforrások, IT-alapú, nagyon nagy sebességú hálózatközpontú megközelítéssel. A közös RF erőforrások kihasználásának legfontosabb eleme a hálózatelemek kalibrációját biztosító csatlakozó felület. Ezen keresztül megoldható az egyes radarok nyújtotta teljes ECCM/EPM spektrum kihasználása, így ezeket közös és rejtett erőforrásként kezelhetik a kapcsolódó polgári és katonai rendszerek felhasználói.

A korszerű radarrendszerek beszerzésének és fenntartásának problematikája rendkívül összetett, és a politikai/ gazdasági elvárások vonzatai meghatározóak lehetnek a projektek sikere vagy bukása területén. Tapasztalatok szerint az élettartamra vetített logisztikai támogatás összege a beszerzési költségek öt-tízszerese. Ezt a döntéshozó szakembereknek időben fel kell ismerniük, mivel a gyorsuló technológiai fejlődés légtérellenőrzésre gyakorolt hatása nagy kockázatokat rejt. A kockázat legfontosabb eleme az, hogy a berendezések vásárlásával legalább 15-20 évre elkötelezzük magunkat egy cég, egy ország szakirányú logisztika (elsősorban IT-szoftver) támogatása mellett.

Az előnyök mellett jelentkező kockázatok csökkentése megköveteli az eszközök teljes élettartamára vonatkozó hazai lehetőségeinek minél szélesebb körű kihasználását és a rendelkezésre álló szakemberek tudásszintjének fenntartását.

IRODALOM

[1] Balajti István: Új kihívások a hazai légtérellenőrzésben, Haditechnika, 2019/2; DOI: 10.23713/HT.53.2.01;

[2] 2018 19th International Radar Symposium (IRS 2018), Proceedings alfejezetek előadásai, 2018. június 20-22, Bonn, Németország. DOI: 10.23919/IRS.2018.8448225;

[3] Military Radar Conference, London, UK, 2018; https:// militaryradar.iqpc.co.uk/ [Letöltés ideje: 2018/08/11];

[4] Deagel news: http://www.deagel.com/news/TRML-3DMobile-Radar-System-Sold-to-Malaysia_n000000642. aspx (Letöltés ideje: 2018/08/11);

[5] IAI Israel: http://www.iai.co.il/2013/34481-41832-en/ Groups_ELTA_EltaNumber_Products-ELM.aspx [Letöltés ideje: 2018/08/11];

[6] Defence 24: Czech Republic Buys Israeli Radar Systems. Fiasco of the Joint V4 Project, 2016 http:// www.defence24.com/czech-republic-buys-israeliradar-systems-fiasco-of-the-joint-v4-project [Letöltés ideje: 2018/08/11].

\title{
Olvasóink figyelmébe!
}

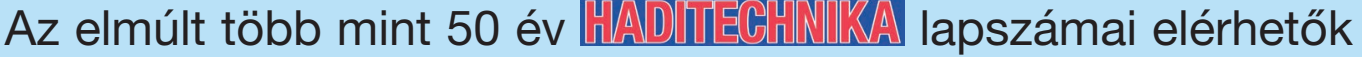 \\ a Magyar Tudományos Akadémia REAL-J repozitóriumában: \\ http://real-j.mtak.hu/view/journal/Haditechnika.html
}

